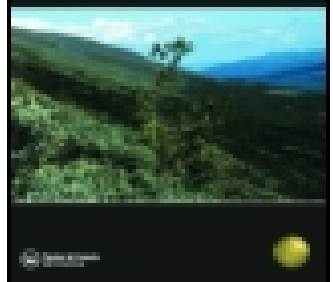

\title{
Borthwickia, A New Genus Of Capparidaceæ
}

\section{W. W. Smith}

To cite this article: W. W. Smith (1912) Borthwickia, A New Genus Of Capparidaceæ, Transactions of the Botanical Society of Edinburgh, 24:1-4, 175-176, DOI: 10.1080/03746601209468957

To link to this article: http://dx.doi.org/10.1080/03746601209468957

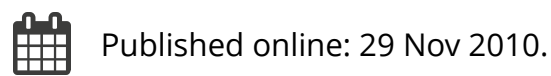

Submit your article to this journal ๔

山 Article views: 3

Q View related articles $\sqsubset$ 
ought to grow as well as Leycesteria formosa in European gardens, but, so far, seeds have not been available. I am indebted to $\mathrm{Mr}$ W. G. Craib, of Kew Herbarium, for kindly comparing the plant with Henry's Yunnan specimen.

\section{Borthwickia, a New Genus of Capparidacee. By W. W. Simth.}

Borthwickia genus novum.

Apud Capparidoideas-Capparideas (Pax); maturo fructu adhuc deficiente locus dubius, interim post. Ritchieam $R$. $B r$. positum est sed etsi frutex, ex affinitate Polanisice esse videtur. Frutex foliis oppositis trifoliatis; petala sex æqualia in latissimum unguem et laminam minorem discreta ; stamina in androphori brevis crassi apice inserta; fructus longe stipitatus 4-6 locularis. Species unica burmanica. Generis nomen honori cl. Alberti Borthwickii scientiæ doctoris et viri re botanica eruditi.

\section{Borthwickia trifoliata, W. W. Smith, sp. nov.}

Planta inermis, altitudine ignota, superior pars in scheda $40 \mathrm{~cm}$. longa. Caulis angulatus, striatus, subcompressus præsertim apud nodos ad $10 \mathrm{~cm}$. remotos, parce minute puberulus, mox glabrescens, racemo terminatus. Folia opposita, rarius subopposita, usque ad $8 \mathrm{~cm}$. petiolata, foliolis tribus lanceolatis acuminatis, basi cuneatis, 7-15 $\mathrm{cm}$. longis, $2-6 \mathrm{~cm}$. latis, $\mathbf{1 - 2} \mathrm{mm}$. petiolulatis, supra glabris, infra in nervis (6-9 paribus) nervulisque rufo-pilosulis. Flores in terminalem racemum densum, in fructu ad $10 \mathrm{~cm}$. auctum, compositi. Bractew $1 \mathrm{~cm}$. longæ filiformes pilosulæ. Pedicelli $5 \mathrm{~mm}$. longi, rufo-pilosuli, in fructu ad $15 \mathrm{~mm}$. aucti. Sepala duo; neque in aperto flore neque in gemma aliorum interiorum sepalium vestigia vidi; $13-14 \mathrm{~mm}$. longa, $5-6 \mathrm{~mm}$. lata, oblonga, obtusa, valvata, in aperto flore ad basim discreta, serius decidua. Petala sex, æqualia, 1-seriata (ideoque duo ut interiora sepala non habenda), valvata, divisa in unguem loriformem, $5 \mathrm{~mm}$. longum, $1.5 \mathrm{~mm}$. latum, villosulum, et in laminam, $3 \mathrm{~mm}$. longam, $1.5 \mathrm{~mm}$. latam, ovatam, glabram, obtusam, minute dentatam, 6-8 nervatam. Stamina in apice androphori $4-5 \mathrm{~mm}$. TRANS. BOT, SOC, FDIN, VOL. XxIV. 
longi inserta, 40-50, 14-16 mm. longa, omnia fertilia, libera, æqualia, filamentis filiformibus, antheris ovalibus, nec oblongis, dorso basi affixis. Ovarium longe stipitatum 4-6 costatum, stigmate sessili, glabrum, 7-8 mm. longum, 4-6 loculare. Fructus immaturus ad $4-5 \mathrm{~cm}$. elongatus, 2-3 mm. latus, carnosulus, seminibus haud multis, multum compressis, reniformibus, $3 \mathrm{~mm}$. longis, gynophoro ad $2-3 \mathrm{~cm}$. aucto.

Burma :-Ad vicum Loi-mwe dictum apud pagos shanenses australes. circ. 1500 ped. alt. 714, 1325, R. W. MacGregor. Typi in herbario Calcuttensi conservati.

\section{DESCRIPTION OF PLATE.}

Figure A. Branch with inflorescence. $\times 1$.

,$\quad$ B. Flower dissected. $\times 2$.

"C. Petal. $\times 4$.

" D. Section or ovary; seed. $\times 2$.

Phaothamion Confervicolum, Lagerheim, and its First Recorded Appearance in Great Britain.* By F. L. M'KeEver, F.R.M.S.

The large class of Algæ, the Phæophyceæ or Fucoideæ (in older books usually called Melanosporeæ), are almost entirely inhabitants of the sea, and only a few families of the order Syngeneticæ are found in fresh water. G. S. West (1) enumerates seven families of this order, and of these only four are represented in Great Britain. I was fortunate enough to find the only member of the fifth family, the Phæothamniaceæ, among other Algæ collected from the Elf Loch on the Braid Hills near Edinburgh, and a few remarks on this plant might be of some interest.

Phæothamnion confervicolum was first described by the Swedish botanist G. Lagerheim, who published his description, together with a very complete life-history, in 1884 (2). He had found this Alga in several localities in Sweden as an epiphyte on various filamentous Chlorophyceæ, and as

* "Annals of Scottish Natural History," No. 77, January 1911. 